\title{
PENYUTRADARAAN DRAMA MUSIKAL HAMLET KARYA WILLIAM SHAKESPEARE
}

\author{
Amanda Putri Devanti \\ Institut Seni Indonesia Yogyakarta
}

\begin{abstract}
Abstrak: Hamlet, sebuah kisah tragedi oleh Shakespeare membawa pesan moral, sosial, dan politik. Drama ini mengisahkan sumpah dan upaya Pangeran Hamlet untuk membalas dendam. Penelitian ini akan menuliskan bagaimana naskah Hamlet diangkat ke dalam bentuk drama musikal, dengan tari, musik, dan nyanyian. Dalam persiapan adaptasi ini, dilakukan pemilihan dan pelatihan aktor serta perancangan panggung dan tata artistik. Drama musikal ini khususnya ditujukan kepada para generasi muda, karena melihat jarangnya teater klasik dengan kemasan masa kini.
\end{abstract}

Kata Kunci: Hamlet, Drama Musikal, Generasi muda

\begin{abstract}
Hamlet, a tragedy written by Shakespeare, is full of moral, social, and political value. This drama tells about Prince Hamlet's vow and effort to get revenge. This research explains how the Hamlet play script is adapted into musical drama, with dance, music, and songs. In preparation for this adaptation, there will be casting and training process for the actors, along with stage and artistic planning. This musical drama is mainly aimed to younger generation to counter the lack of classic theatre in modern style.
\end{abstract}

Key Words: Hamlet, Drama Musical, Young generation

\section{Pendahuluan}

Sastra drama adalah sebuah karya tulis berupa rangkaian dialog yang mencipta atau tercipta dari konflik batin atau fisik yang memiliki kemungkinan untuk dipentaskan (Riantiano, 2011). Aliran sastra drama yang mempunyai batasan-batasan tertentu, salah satunya yaitu aliran sastra drama klasik. Konvensi atau aturan penulisan diikuti dengan sangat ketat. Misal, lakon harus diikat oleh struktur dan jumlah babak yang baku (Riantiano, 2011). Banyak karya drama klasik yang diciptakan oleh sastrawan dunia, yaitu Sophocles, Aeschylus, Euripides dan William Shakespeare.

Nano Riantiarno mengatakan bahwa pada masa Ratu Elizabeth di Inggris, muncul empu-empu drama yang karyanya hingga kini masih dipentaskan di seluruh dunia. Di antaranya, yang paling berpengaruh adalah
William Shakepeare

(1564-1616)

(Riantiarno, 2011). William Shakespeare adalah seorang sastrawan yang mempunyai karya-karya besar. Karya-karyanya menginspirasi banyak orang, sehingga karyanya dipentaskan di seluruh dunia. Shakespeare lahir pada 26 April 1564 di Stratford-upon-Avon, Inggris. Pada umur 18 tahun, Shakespeare menikahi Anne Hathaway yang umurnya delapan tahun lebih tua darinya dan di karuniai tiga anak, yaitu Susanna dan dua anak kembarnya yang bernama Hamnet dan Judith. Banyak orang berpikir bahwa Shakespeare mendapatkan inspirasi dari anaknya Hamnet yang pada tahun 1596 meninggal dunia, kemudian Shakespeare menulis The Tragical History of Hamlet, Prince of Denmark.

Lakon drama Shakespeare selalu menggunakan bahasa yang puitik. William Shakespeare empu drama dari Inggris, 
naskahnya sangat sastrawi, bahkan puitis. Dia menulis dalam bentuk puisi (sonata) atau sanjak-sanjak (Riantiano, 2011). Seorang sastrawan yang mempunyai banyak karya, pasti mempunyai ciri-ciri dari karyanya. Berikut ciri-ciri karya Shakespeare:

Ciri-ciri umum dari dramanya: a. titik awal kebangkitan; b. beberapa pementasan (subplot) awalnya bersifat mandiri kemudian bergabung, kesatuan dalam keragaman yang tampak jelas.(King Lear); c. sejumlah peristiwa yang bervariasi: gabungan antara tawa dan air mata, hasrat/keinginan yang halus dan kasar; d. waktu dan tempat yang bebas; e. karakter berjumalah banyak, biasanya 30 . Kaya dan miskin, semuanya bersifat perseorangan; $\mathrm{f}$. bahasa yang digunakan bervariasi: elegan, kasar, jenaka, sehari-hari, semuanya sesuai karakter dan permainan; g. ide cerita dari banyak sumber (dongeng, sejarah, legenda, fiksi, drama), namun ditafsir ulang dan dengan cara yang khas Shakespeare (Riantiano, 2011).

Selain hal tersebut, ciri drama Shakespeare juga membawa kebiasaan zamannya yaitu: a. penggunaan Blank Verse; b. Soliloqui; c. dialog ke samping (Aside); d. pidato; e. penyamaran (pada komedi) (Sumardjo, 1986).

Salah satu cerita klasik karya William Shakespeare yang tak lekang sepanjang zaman adalah Hamlet. Hamlet adalah sebuah cerita klasik dalam bentuk tragedi.

Penderitaan Hamlet mencari kebenaran, membela kehormatan ayahnya, membela kasih sayangnya pada ibunya, membunuh ular yang menusuk hidup ayahnya, membebaskan Denmark dari rezim yang jahat dan racun yang disebarkan Claudius. Dan juga penting membunuh cintanya yang kemudian dia tangisi sejadi-jadinya (Haryono, 2000).

Banyaknya permasalahan yang dialami Hamlet membuatnya kacau, karena terlibat dalam banyak orang dengan permasalahannya sendiri-sendiri. Hamlet adalah ibarat sebatang pohon yang dibebani dengan dahan, ranting, daun, mungkin juga debu dan kotoran burung atau juga mungkin nasib pohon ini disambar petir (Haryono, 2000). Cerita ini mengandung pesan moral bahwa kedua belah pihak yang sama-sama tidak ingin memaafkan, menyebabkan suatu musibah yang membuahkan tragedi yang lebih besar dan tragis. Cerita yang mengandung banyak pesan moral ini juga mengandung unsur politik. Seperti apa yang diceritakan dalam naskah ini, melihat kondisi bangsa kita saat ini. Banyak kelicikan yang muncul untuk mendapatkan suatu kepuasan pribadi bagi para pemimpin dengan membohongi rakyatnya. Tidak hanya kisah Hamlet saja yang mengandung pesan moral dan politik, akan tetapi pesan tersebut juga ada pada beberapa naskah lainnya. Drama-drama klasik semacam Phaedra dan Oedipus the King sering dianggap sebagai demonstrasi-demonstrasi moral atau politik dalam karya drama (Sahid, 2012).

Hamlet karangan William Shakespeare dipilih oleh penulis untuk mewujudkan keinginan mengangkat cerita klasik dalam pertunjukan teater modern yaitu drama musikal. Kecenderungan masyarakat saat ini, musikal masih jarang menampilkan naskah klasik. Hamlet dibayangkan menjadi sebuah pertunjukan drama musikal yang memikat.

Teater adalah permainan (pekerjaan, makanan, pelatihan) bagi jiwa, pikiran dan tubuh. Pekerjaan tanpa permainan tentu bisa membosankan. Paling tidak, kita bisa melihat teater dari 4 cara, sebagai hiburan atau Hiburan, sebagai alat pendidikan, sebagai senjata social/politik, sebagai dokumen sejarah (Riantiarno, 2011). 


\section{Penelitian Sebelumnya}

Seiring dengan perubahan zaman, perkembangan pertunjukan cerita klasik dalam bentuk modern di Indonesia masih jarang diketahui masyarakat, terutama pada generasi muda. Banyak yang mengenal cerita Hamlet, namun untuk mengolahnya menjadi teater modern, di Indonesia masih sangat jarang.

"Banyak aktor dan sutradara yang sudah lebih dari seribu kali memainkan dan mementaskan Hamlet, sehingga tuntas habis semua segi pemikiran dan kompleksitas penghayatan digali dan diekspreksikan. Tetapi di dalam kehidupan teater modern Indonesia yang belum mapan sampai saat ini, kesempatan untuk mengulang kembali pementasan satu repertoir itu masih langka" (Haryono, 2000).

Generasi muda saat ini memilih halhal yang lebih menarik, seperti memilih menonton pertunjukan modern dari pada menonton pertunjukan klasik, sehingga cerita-cerita atau rekaman peristiwa klasik seperti jarang terlihat lagi. Hal ini kemudian penulis jadikan sebagai spirit dalam berkarya dengan mengenalkan kembali kisah klasik tersebut kepada masyarakat melalui peristiwa teater dalam bentuk teater modern. Penulis mengharapkan kisah ini dapat dikomunikasikan kepada penonton, sehingga nantinya, penonton dapat melihat segala situasi tentang cerita klasik dalam media panggung yang berbeda. Penulis sekaligus sutradara menjadikan tontonan nantinya sebagai hiburan, dengan memasukkan beberapa unsur sebagai penunjang demi mewujudkan efek hiburan yang dimaksud (nyanyian dan tarian).

\section{Teori Penciptaan}

Drama memiliki struktur dan tekstur yang khas. Dalam analisis struktur dan tekstur, seorang kritikus maupun sutradara dapat menelusuri kembali secara sistematis langkah-langkah yang diambil penulis dalam menuangkan gagasannya dalam drama (Dewojati, 2012). Aspek struktur dan aspek tekstur yang menjadi pijakan untuk menganalisis sebuah naskah drama.

Memilih pemain aktor dan aktris juga merupakan tahap awal dalam kerja penyutradaraan. Sutradara tidak asal untuk memilih aktor dan aktris dalam pementasannya, sehingga mempunyai cara tersendiri untuk menentukan pemain. Ada beberapa tahapan untuk menentukan pemain, yaitu sebagai berikut:

a. Casting by Ability : Casting yang didasarkan pada kecakapan, pemain yang terpandai dan terbaik dipilih untuk peran yang penting atau utama dan sukar.

b. Casting to Type : Pemilihan berdasarkan kecocokan fisik pemain.

c. Antitype Casting : Pemilihan yang bertentangan dengan watak atau fisik si pemain, menentang keumuman jenis perwatakan manusia secara konvensional, sering disebut educational casting.

d. Casting to Emotional Temprament : memilih seseorang berdasarkan hasil observasi hidup pribadinya, karena mempunyai banyak kesamaan atau kecocokan dengan peran yang akan dipegangnya (kesamaan emosi, tempramen, dan lain-lain)

e. Theurapeutic-casting : menentukan seorang pelaku yang bertentangan dengan watak aslinya dengan maksud menyembuhkan atau mengurangi ketidakseimbangan jiwanya.

\section{Metode}

Agar tidak hanya sekedar memindahkan naskah drama ke dalam panggung, maka sutradara merancang ide dengan hasil analisis naskah dengan metode sebagai berikut:
1. Struktur

a. Tema 
Tema dari naskah Hamlet adalah "Balas dendam." Tema tersebut dijadikan sebagai dasar pertunjukan untuk mewujudkan gagasan sutradara.

b. Alur

Alur dalam naskah Hamlet karya William Shakespeare yaitu alur linier, yaitu cerita dipaparkan secara berurutan di mana peristiwa yang terjadi akibat dari peristiwa sebelumnya sehingga diikuti dengan hubungan sebab akibat yang jelas antara setiap peristiwanya.

c. Penokohan

Sutradara menggunakan akting dengan gaya drama musikal sebagai dasar keaktoran, meskipun di adegan tertentu sutradara menambah akting dengan gaya karikatur yang membutuhkan keaktoran dengan tipe improvisasi pada adegan gurauan.

d. Latar

Sutradara menentukan latar tempat kejadian di Denmark pada tahun 15991601. Latar tersebut dijadikan sebagai dasar tata artistik yang menentukan wujud setting dan properti, kostum, pencahayaan serta musik.

2. Tekstur

a. Suasana

Suasana yang ada di naskah Hamlet adalah suasana tegang yang tergambar pada bebeapa adegan yaitu adegan pertama adalah adegan perang, kelima adegan terbunuhnya Polonius, keenam adegan matinya Ophelia dan kedelapan adegan pertandingan dan perang. Selain itu suasana lain yang ada dalam naskah ini yaitu suasana peperangan, suasana duka, suasana meriah dan ceria ketika adegan pernikahan. b. Dialog

Pada pertunjukan drama musikal Hamlet menggunakan bahasa yang puitis dan terkandung soliloque serta aside. Soliloque mengungkapkan hal-hal yang sedang dipikirkan tokoh untuk dilaksanakan. Aside merupakan lontaran pikiran berupa komentar atau kritikan terhadap adegan yang sedang berlangsung. c. Spektakel

Spektakel pada pertunjukan drama musikal Hamlet berupa adanya unsur tarian, nyanyian, kostum, setting yang menggambarkan latar di sebuah kerajaan di Denmark dan dikombinasikan dengan video mapping.

Penulis sebagai sutradara juga melakukan dengan sistem menyeleksi atau casting pemain pada proses Hamlet secara : a. Casting by Ability

Sutradara menentukan pemain berdasarkan kecakapan untuk mendukung pertunjukan drama musikal Hamlet. Kecakapan terdiri dari cara bicara, tubuh dan penghayatan serta kecakapan khusus.

Dalam cara bicara, pemain harus mempunyai kemampuan wicara yang baik karena kejelasan mengucapkan dialog merupakan kunci tersampainya pesan dialog terhadap penonton. Sutradara dapat menilai dengan memperhatikan diksi, intonasi dan pelafalan.

Sutradara membutuhkan kesiapan tubuh untuk memerankan beberapa adegan perang. Penilaian dilakukan dengan cara latihan ketahanan tubuh pada saat menentukan pemain karena tubuh yang lemah sangat tidak menguntungkan.

Penghayatan sangat dibutuhkan dalam memerankan sebuah tokoh. Mampu menerjemahkan laku aksi sebuah karakter dalam ekspresi tubuh maupun bahasa verbal secara beriringan. Agar dapat menilai hal tersebut, sutradara mencoba memberikan penggalan dialog karakter tokoh pada naskah Hamlet untuk diujikan.

Sutradara membutuhkan kemampuan lain (kecakapan khusus) selain berperan. Hamlet dengan konsep drama musikal yang di dalamnya terdapat beberapa adegan perang, menari dan menyanyi, membutuhkan aktor yang 
memiliki kemampuan bernyanyi dan menari.

b. Casting to Type

Kecocokan fisik seorang aktor dapat menjadi dasar untuk menentukan peran. Dalam proses menentukan pemain, sutradara menggunakan fisik yang terdiri dari ukuran tubuh, tinggi tubuh dan ciri wajah sebagai acuannya.

\section{Pelatihan Aktor}

\section{Penanaman Minat dengan Reading}

Reading adalah tahapan awal dalam proses pembentukan cerita yang akan dihidupkan dalam pertunjukan (Susantono, 2016). Membaca naskah lakon dengan cermat dan teliti yang diarahkan sutradara merupakan salah satu bentuk menganalisis sebuah naskah.Sutradara mempunyai beberapa tahapan dalam membaca naskah. Pada tahap pertama sutradara memberi instruksi kepada para aktor untuk membaca naskah berulang kali dan menuliskan catatan kecil dinaskah masing-masing guna memahami makna dan tujuan setiap kata pada dialog tokohnya masing-masing. Pada tahap kedua, para aktor membaca naskah per suku kata dengan pelan dan teliti. Pada tahap ketiga, Pada tahap keempat, para aktor membaca naskah dengan mencari hubungan antar satu kata dengan kata lainnya maupun satu kalimat dengan kalimat lainnya. Pada tahap keempat, membaca kembali dengan teliti dan menganalisis tiga dimensi tokoh masing-masing aktor. Pada tahap ini sutradara mulai menyarankan untuk memperdalam tokoh masing-masing dengan mencari referensi tokohnya. Pada tahap kelima, sutradara menginstruksikan kepada para aktor untuk membaca dengan dramatik sesuai emosi dialognya agar peristiwa terbangun.

2. Penanaman Bakat

a. Latihan Bernyanyi
Latihan Bernyanyi dilakukan agar dapat mewujudkan adegan-adegan yang terdapat nyanyian di dalamnya. Berikut langkah-langkah melatih vokal para aktor: para aktor melakukan olah vokal. Olah vokal dipimpin oleh music director, kemudian dilanjutkan dengan menyanyikan lagu masing-masing aktor. Setelah menyanyikan lagu perbagian-bagian pada masing-masing aktor, maka selanjutnya dengan bersama-sama melakukan singthrough seluruh lagu dalam pertunjukan secara berurutan sesuai urutan adegan.

Langkah-langkah tersebut dilakukan setelah olah tubuh dan sebelum masuk adegan. Selain itu, sutradara juga mengadakan latihan musik secara parsial dilain hari latihan gabungan. Hal ini dilakukan agar para pemusik dapat melakukan pencarian dan para aktor diharapkan dapat mengejar vokal yang kurang baik.

\section{b. Latihan Menari}

Pada latihan tari, aktor tidak dipaksakan jadi penari namun seolah-olah menjadi penari. Sutradara juga mengadakan latihan parsial khusus tarian di luar latihan gabungan. Berikut langkah-langkah melatih gerakan pada aktor: Pertama, olah tubuh yang dipimpin oleh koreografer. Kedua, koreografer mengajarkan dasar-dasar tari ballet karena di dalam pertunjukan ini mengambil spirit dari tari ballet. Ketiga, koreografer mengajarkan sikap-sikap tari ballet. Keempat, koreografer memberikan sebuah koreografi yang mengandung levelitas dan komposisi. Kelima, para aktor diharapkan untuk menghafalkan gerakangerakan per adegannya. Keenam, sutradara merapikan hasil dari gerakan agar dapat terlihat rampak dan rapi. Ketujuh, sutradara memberikan bloking pada aktor ketika menari diatas panggung. Kedelapan, sama halnya seperti latihan bernyanyi, latihan tari 
juga melakukan dance-through koreografi sesuai urutan adegan dalam pertunjukan.

Melatih gerakan pada para aktor juga dibutuhkan kekompakan pada koreografer dan sutradara, karena setelah dari tangan koreografer yang memberi gerakan, selanjutnya sutradara memberi bloking dan merapikannya kembali agar terlihat rampak dan rapi.

\section{c. Latihan Gerak dan Musik}

Sutradara juga memberikan latihan gerak dan musik terhadap para aktoraktornya. Hal ini dilakukan agar menjaga keseimbangan antara gerak dan musik. Selain itu juga menghindari kualitas vokal yang tidak bagus ketika dilakukan sambil menari, begitu pula sebaliknya.

\section{Latihan Gabungan atau Latihan Rutin} a. Latihan Blocking

Blocking merupakan garis yang diberikan oleh sutradara yang bertujuan untuk memberikan makna sesuai dengan motivasi. Blocking adalah aturan berpindah tempat dari tempat yang satu ke tempat yang lain (Tambajong, 1981). Pada latihan Blocking, sutradara memberikan keleluasaan kepada para aktor/aktris untuk bergerak kemudian akan mengoreksi dan memberikan arahan sesuai dengan konsep pertunjukan.

\section{b. Cut to cut dan Runthrough}

Dalam latihan Cut to cut sutradara memperbaiki secara langsung adegan demi adegan ketika para aktor sedang bermain memeragakan adegan. Biasanya pendetailan dilakukan pada latihan cut to cut. Sedangkan Runthrough adalah latihan di mana seluruh materi pertunjukan sudah lengkap dari awal hingga akhir (Tambajong, 2016). Pada saat runthrough sutradara mempercayai stage manager untuk mengambil alih komando dan memimpin stage. Pada saat evaluasi sutradara berhak memberi saran dan kritik terhadap setiap pemain. Stage manager biasanya juga menginformasikan durasi ketika selesai runthrough. Hal tersebut dilakukan agar sutradara dapat menakar durasi pementasan saat pertunjukan berlangsung.

4. Gladi Kotor

Gladi kotor merupakan hal yang harus dilakukan. Pada saat gladi kotorlah hal-hal teknis sudah harus dicoba. Mulai dari teknis pergantian kostum hingga teknis yang berhubungan dengan setting. Stage manager juga membiasakan untuk mengkondisikan para pemain di side wings kanan dan kiri agar tidak berisik dan tidak terlihat penonton. Ketika gladi kotor, biasanya sutradara membenahi dan terus mengulang apa yang perlu dikoreksi sampai memuaskan. Selain itu juga melakukan runtrough pada gladi kotor. Bahkan pada gladi kotor sutradara masih berhak mengoreksi dan membenahi musik apabila suara musik terlalu keras sehingga dialog para aktor tidak terdengar. Evaluasi sutradara pada saat gladi kotor sangat penting, bahkan kritik dan saran pengamat yang hadir juga sangat berarti dan dapat disampaikan ketika evaluasi. Ketika gladi kotor, para pemain mempunyai catatan dan tugas masing-masing untuk dibenahi agar tidak terulang lagi ketika gladi bersih.

5. Gladi Bersih

Gladi bersih hal yang wajib dilakukan, karena gladi bersih merupakan latihan pentas sebenarnya. Biasanya para pemain sudah memakai kostum dan make up pada saat runthrough. Sutradara melakukan gladi bersih agar para pemain dan tim benarbenar merasakan suasana pentas yang sebenarnya. Pada gladi bersih sudah tidak lagi sibuk dengan teknis bahkan seharusnya sudah tidak ada lagi kesalahan dalam hal teknis maupun non teknis. Dari sinilah seluruh tim pendukung dapat memperkirakan kesiapan masing-masing. Sutradara juga dapat melihat kemungkinankemungkinan buruk yang harus segera diatasi. 


\section{Perancangan tata artistik}

Perancangan tata artistik dalam pementasan drama musikal Hamlet meliputi, tata pentas, tata bunyi dan musik, tata lampu, tata busana dan tata rias.

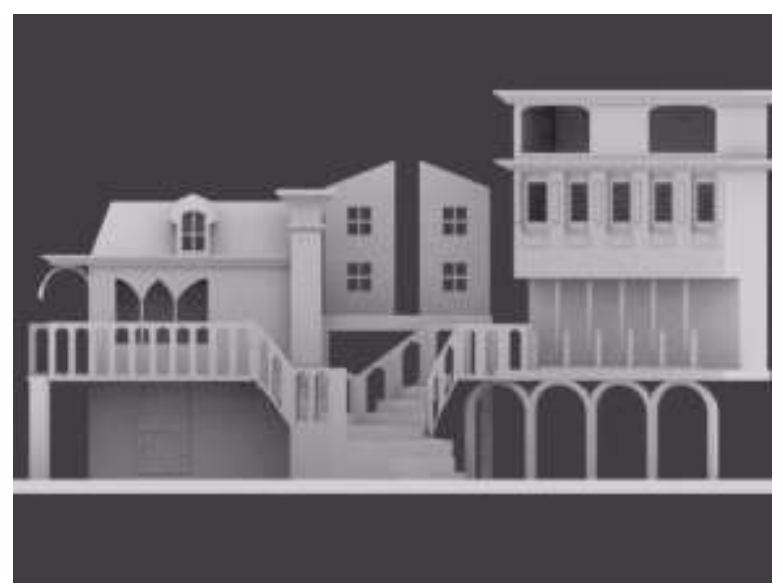

Gambar 1. Sketsa Panggung

(Desain : Aldi, 2018)

\section{Tata Pentas}

Sutradara mementaskan drama musikal Hamlet dengan memilih panggung proscenium, dengan panggung yang terlihat seperti bingkai. Dekorasi atau set adalah pemandangan atau latar belakang tempat memainkan lakon dan memungkinkan memberikan perwatakan pada tokoh atau lakon (Harimawan, 1993).

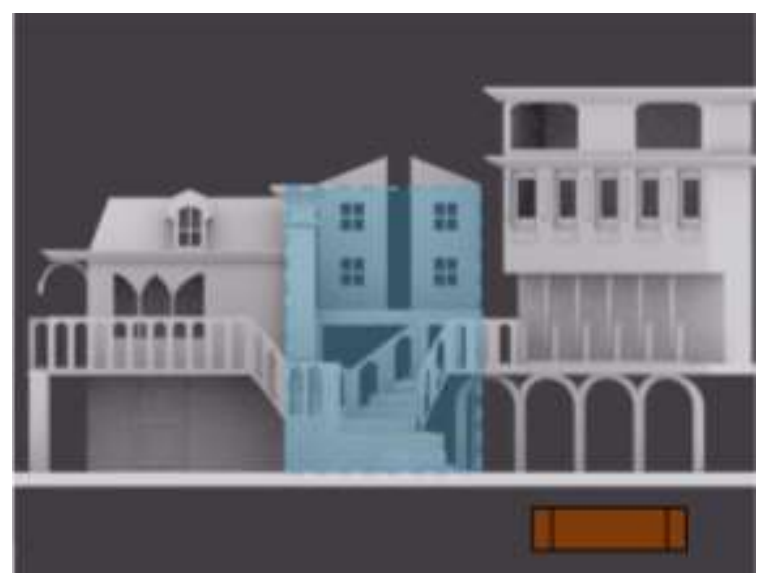

Gambar 2. Sketsa Panggung adegan

Polonius terbunuh

(Desain : Aldi, 2018)
Konsep setting yang digunakan adalah multi setting. Berikut pemaparan rancangan setting :

\section{Tata Bunyi dan Musik}

Secara umum, musik dalam drama musikal dibagi ke dalam dua bagian utama, yaitu lagu dan underscore (Susantono, 2016). Lagu-lagu dalam drama musikal mempunyai fungsi dramatik agar memperkuat emosi. Maka, lagu yang akan dinyanyikan oleh seorang aktor adalah lagu yang sesuai dengan karakter tokoh aktor tersebut. Underscore adalah alunan musik yang mengiringi aksi atau peristiwa. Underscore memiliki beberapa fungsi (Susantono, 2016), yaitu: dramatisasi, atau meninggikan emosi dalam sebuah aksi atau peristiwa, mengomunikasikan mood atau suasana tertentu, memberikan tema untuk suatu lokasi atau tokoh, dan mengiringi transisi.

Sutradara memiliki beberapa langkah untuk membuat lagu dan underscore yang dibantu oleh komposer. Berikut langkahlangkah nya:

a. Sutradara dan komposer melakukan reading naskah Hamlet secara bersama.

b. Sutradara dan komposer membedah naskah Hamlet agar dapat mengetahui suasana di tiap adegannya.

c. Sutradara dan komposer menentukan tema musik keseluruhan.

d. Sutradara dan komposer menentukan tema musik untuk masing-masing tokoh dalam naskah tersebut.

e. Sutradara dan komposer menentukan tema musik pada tiap adegan,

f. Sutradara memberitahu suasana yang sedang dirasakan oleh tokoh ketika sedang bernyanyi di tiap adegannya.

g. Komposer membuat lagu masingmasing aktor sesuai arahan sutradara.

h. Setelah komposer membuat lagu, sutradara menyampaikan kepada aktor 
dan memberi arahan ketika bernyanyi termasuk bloking saat bernyanyi serta memberi emosi untuk mengisi rasa pada lirik lagu tersebut.

Hal tersebut akan dijadikan dasar dalam pembuatan musik pada proses Hamlet. Seperti halnya koreografer, sutradara dan komposer harus mempunyai kekompakan untuk membuat suatu karya yang baik. Berikut notasi musik pada drama musikal Hamlet :

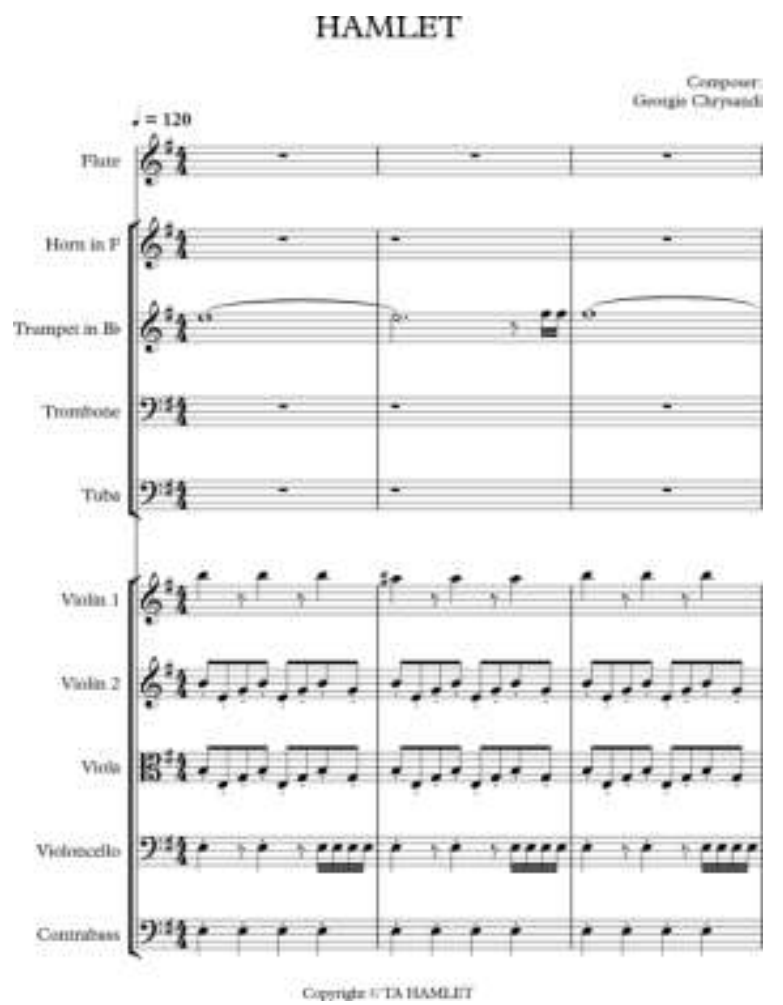

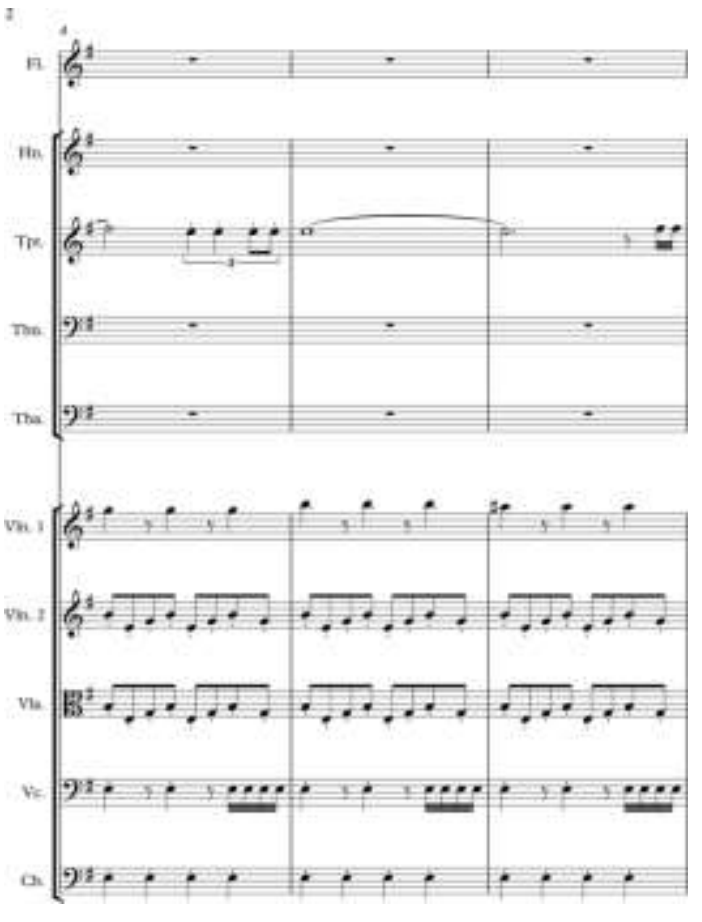

\section{Tata Cahaya}

Tata cahaya tak hanya sekedar memberikan efek terang saja tetapi juga memberikan penerangan dengan intensitas tertentu. Hal ini dilakukan agar dapat menciptakan dimensi dengan membagi sisi gelap dan terang objek yang akan disinari. Area diatas panggung diatur dengan tujuan tertentu agar dapat menegaskan pesan yang akan disampaikan oleh aktor, sehingga tidak semua area panggung mempunyai tingkat terang yang sama.

Sistem pencahayaan pada pementasan drama musikal Hamlet dibagi menjadi dua tempat yaitu area apround dan area stage. Berikut rancangan tata cahaya pertunjukan drama musikal Hamlet : 


\section{PLOT LIGHT}

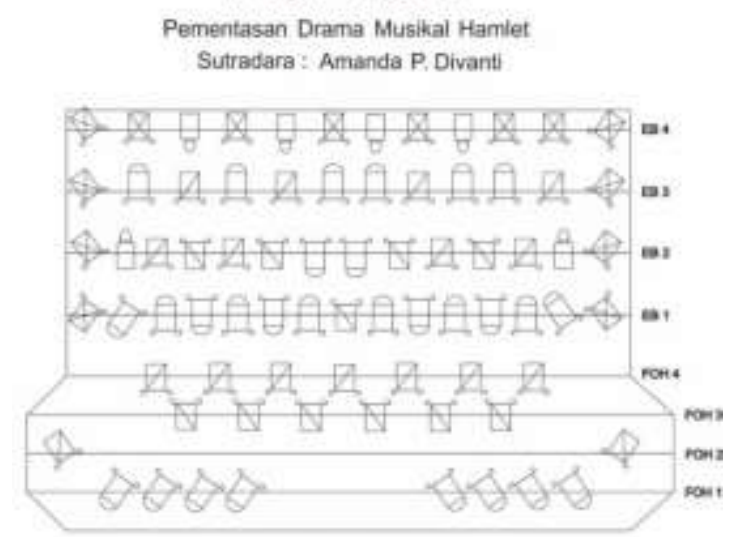

Keterangan :

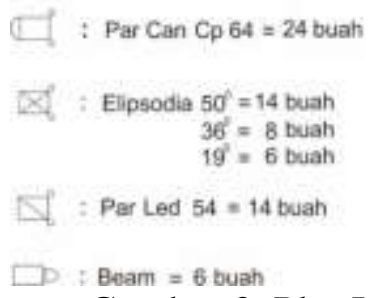

Gambar 3. Plot Lampu Pertunjukan

(Sketsa : Ibnu dan Alfan Dion, 2018)

4. Floor Plan Pementasan Drama Musikal Hamlet oleh Sutradara Amanda P Divanti

\section{BACKSTAGE}

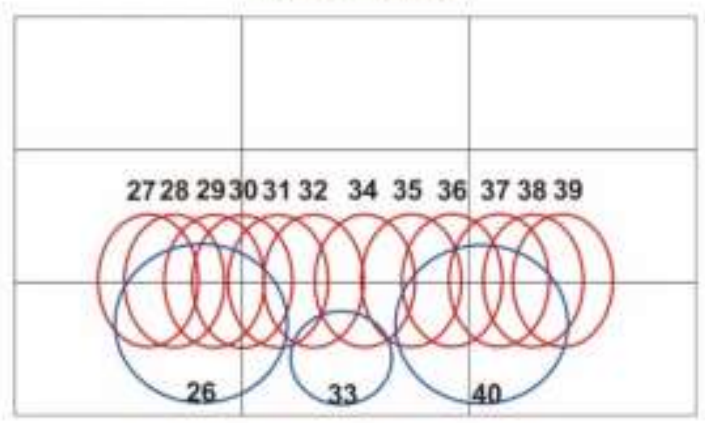

\section{AUDIENCE}

18

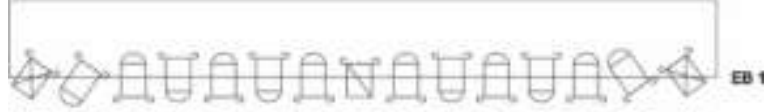

$\begin{array}{lllllllllllllll}26 & 27 & 28 & 29 & 30 & 31 & 32 & 33 & 34 & 35 & 36 & 37 & 38 & 39 & 40\end{array}$ ${ }_{29} \quad \frac{L}{30} \quad \frac{L}{31} \quad \frac{L}{32} \quad \frac{L}{33} L_{34}$

Gambar 4. Sketsa Floor Plan Batten 1 (Sketsa : Krisna Megumi dan Alfan Dion, 2018)

\section{BACKSTAGE}

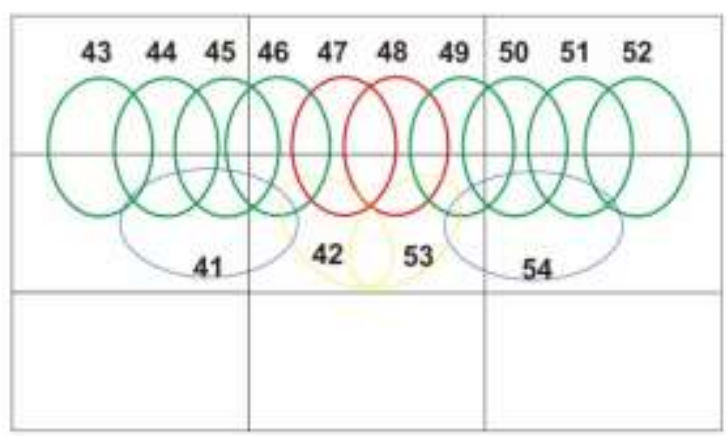

20

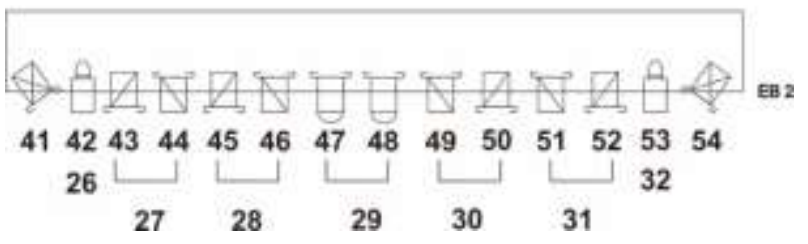

Gambar 5. Sketsa Floor Plan Batten 2 (Sketsa : Krisna Megumi dan Alfan Dion, 2018)
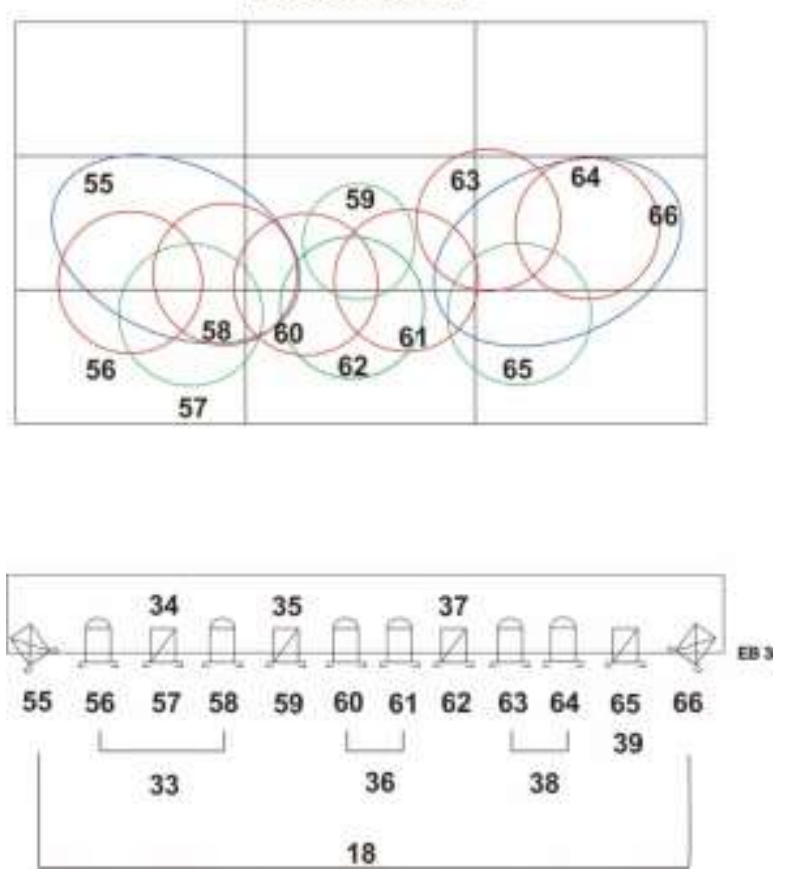

Gambar 6. Sketsa Floor Plan Batten 3 (Sketsa : Krisna Megumi dan Alfan Dion, 2018) 


\section{BACKSTAGE}

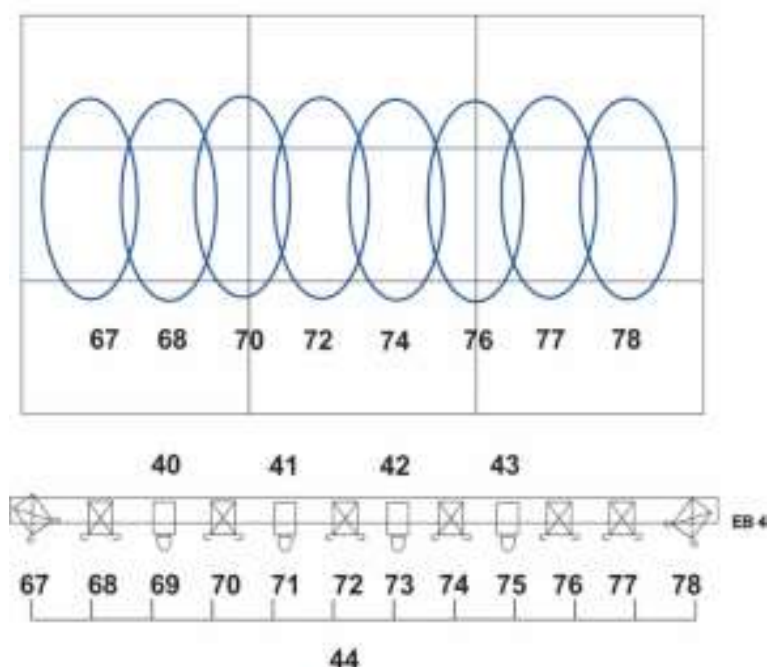

Gambar 7. Sketsa Floor Plan Batten 4 (Sketsa : Krisna Megumi dan Alfan Dion, 2018)

\section{Tata Busana}

Busana dalam pertunjukan teater menggambarkan identitas seorang tokoh. Busana setiap tokoh juga menjadi sebuah pembeda karakter tokoh lain. Sehingga sutradara harus cermat memilih warna, bahan dan motif sesuai dengan hasil analisis penokohan pada naskah Hamlet. Selain itu, mendesain tata busana drama musikal berbeda dengan desain tata busana lainnya. Desain tata busana drama musikal tantangan tersendiri (Susantono, 2016), yaitu:

a. Analisis tokoh - kostum seorang tokoh harus mampu menggambarkan kepribadiannya. Dari analisis tokoh, desainer dapat secara tepat merencanakan unsur-unsur simbolis yang akan terbawa pada kostum

b. Extra engineering - berkaitan dengan bentuk, pengukuran, bahan, jenis potongan. Tak hanya untuk tokoh yang menari, secara garis besar, keleluasan aktor untuk berekspresi adalah salah satu prioritas utama dalam mendesain kostum. Kostum yang baik seharusnya dapat memperluas range ekspresi aktor, bukan mempersulit

c. Eksposisi dan diferensiasi tokoh - drama musikal pada umumnya melibatkan banyak aktor. Setiap tokoh penting harus dapat dibedakan secara visual dengan tokoh yang lain, sekalipun oleh penonton yang duduk dibalkon paling atas dan kursi paling belakang.

Tata busana dalam pementasan ini menggunakan gaya Eropa yang dibawa ke Modern.

6. Tata Rias

Rias wajah dan rambut adalah penciptaan yang dilukis pada wajah dan penataan rambut (Riantiarno, 2011). Tujuan tata rias yaitu untuk memperjelas wajah dan ketokohan masing-masing pemain. Tata rias terdiri dari tiga macam, yaitu korektif, karakter dan fantasi (Riantiarno, 2011). Tata rias dalam pementasan Hamlet, berdasar pada make-up korektif dan make-up karakter. Tata rias korektif bertujuan untuk memperjelas wajah pemain agar terlihat dari jauh. Sedangkan tujuan tata rias karakter yaitu untuk memperjelas karakter pemain. Misalnya menjadi pemarah, tua, licik maupun jelek.

\section{Simpulan}

Setelah melewati beberapa pokok bahasan tentang proses kreatif pertunjukan drama musikal Hamlet, maka akhirnya sampailah pada kesimpulan dari seluruh pembahasan. Penulis sekaligus sutradara pada pementasan drama musikal Hamlet telah melalui banyak tahapan dari awal proses hingga sampai tahap pagelaran. Pementasan drama musikal Hamlet merupakan sebuah proses kreatif yang bekerja secara kolektif melibatkan banyak unsur di dalamnya. Mulai dari memilih naskah, memilih bentuk pertunjukan yang kemudian dilanjutkan dengan merancang ide. 


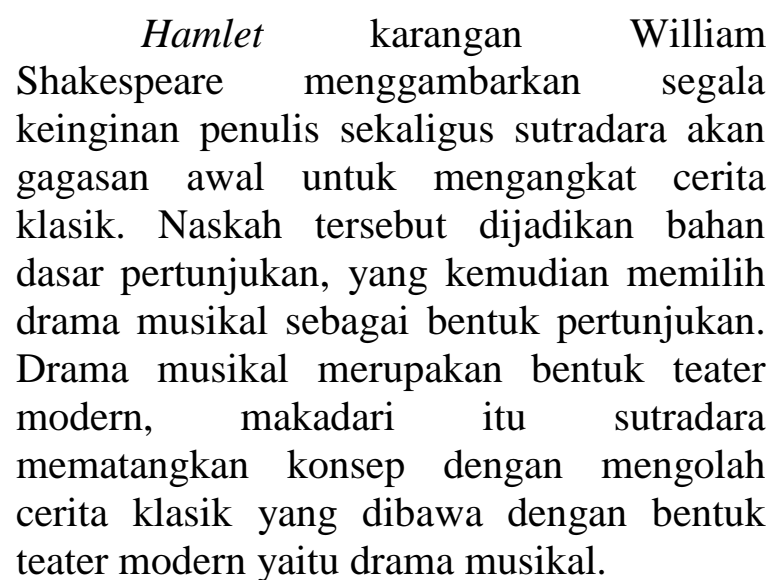

Penulis sebagai sutradara, dalam perjalanan proses latihan menemukan pemahaman baru dan juga menemukan kendala yang menghambat jalannya proses latihan. Kendala tersebut dapat dihadapi hingga pada pementasan dengan dibantu oleh tim kreatif yang telah memiliki komitmen untuk mewujudkan ide sutradara dalam sebuah pementasan.

Naskah Hamlet karya William Shakespeare ini dipentaskan pada tanggal 6 dan 7 Juli 2018 pukul 16.00 dan 20.00 di Concert Hall, Taman Budaya Yogyakarta, Jl. Sriwedani, Kota Yogyakarta, Daerah Istimewa Yogyakarta. Pementasan tersebut diapresiasi penonton sebanyak 1.234 orang yang membuktikan bahwa masyarakat saat ini tertarik untuk menonton sebuah pertunjukan dengan bentuk drama musikal. Drama musikal Hamlet merupakan sebuah pementasan kolosal yang melewati proses panjang. Disini, penulis sebagai sutradara tidak dapat hadir sendiri tanpa bantuan seluruh tim pendukung.

Dalam memimpin sebuah proses kreatif pementasan kolosal diperlukan perencanaan yang matang. Selain itu jumlah pemain juga menjadi bagian penting karena dipentaskan secara kolosal. Penulis menyarankan agar setiap sutradara yang akan menggarap pementasan terutama pementasan kolosal, harus memberikan beberapa aturan proses yang tepat agar target sutradara dapat terselesaikan dengan baik.

Banyak unsur yang terlibat dalam mewujudkan sebuah pementasan kolosal baik pemain maupun seluruh tim kreatif yang terlibat. Sutradara harus mempunyai metode tertentu untuk mengendalikannya. Metode tersebut dapat diterapkan jika target sutradara bergeser, pemain tidak lengkap pada saat latihan dan sebagainya agar proses tetap berjalan dengan lancar.

\section{Daftar Pustaka}

Dewojati, C. (2012). DRAMA: Sejarah, Teori dan Penerapannya. Yogyakarta: Javakarsa Media.

Harimawan. (1993). Dramaturgi. Bandung: PT Rema Rosdakarya.

Haryono, E. (2000). Rendra dan Teater Modern Indonesia. Yogyakarta: Kepel Press.

Riantiarno, N. (2011). Kitab Teater. Jakarta: Gramedia Widiasarana Indonesia.

Sahid, N. (2012). Buku Ajar Matakuliah Semiotika Teater (Teori dan Penerapanny). Yogyakarta: Perpustakaan ISI Yogyakarta.

Sumardjo, J. (1986). Ikhtisar Sejarah Teater Barat. Bandung: Angkasa Bandung.

Susantono, N. P. (2016). Produksi Drama Musikal. Jakarta: PT Gramedia Pustaka Utama.

Tambajong, J. (1981). Dasar-dasar Dramaturgi. Bandung: Pustaka Prima. 